\title{
OBITUARY
}

\section{Professor Herbert Lochs}

European Journal of Clinical Nutrition (2015) 69, 537-538; doi:10.1038/ejcn.2015.62

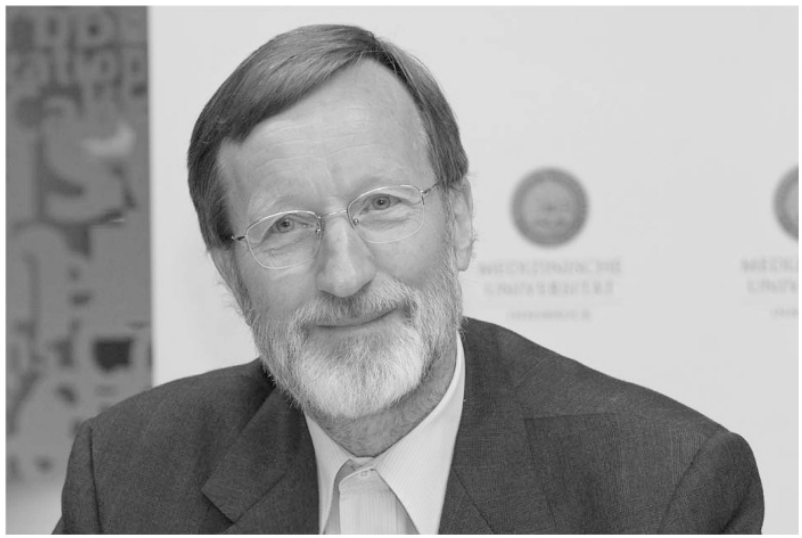

Leader in Clinical Nutrition and Gastroenterology, born in 1946 in Innsbruck, Austria, died due to cancer in Innsbruck, on 10 February 2015, aged 69 years.

Herbert Lochs was a great and empathetic clinician, an outstanding scientist and a broadly cultured humanist. He was passionate about his work and spent much of his working life dedicating his time to furthering his knowledge for the good of others. Working and discussing with him was interesting and rewarding for all_colleagues, patients, students and friends. He was always equipped with thought provoking questions based on his desire to learn and to advance the field.

During his carreer, Herbert Lochs strived to account basic as well as clinical science. He began his career at the Institute of Pharmacology at the University of Innsbruck working on the metabolism of catecholamines. ${ }^{1}$ He then moved to Vienna becoming a specialist of internal medicine and gastroenterology. From 1984 to 1986, he worked at the Clinical Nutrition Research Unit, University of Pittsburgh School of Medicine, and Institute of Nutrition, together with Professor Siamak A. Adibi, where his research interests began to concentrate on the biochemistry ${ }^{2,3}$ and organ-specific metabolism of dipeptides; ${ }^{4-7}$ this research was fundamental and at that time produced some breathtaking results. A number of years later, Herbert Lochs continued his work on dipeptides by addressing their therapeutic value in patients with inflammatory bowel disease. ${ }^{8}$ Back in Europe, he was one of the first to establish a clinical nutrition unit at the Vienna General Hospital, which is the University Medical Center of the city of Vienna. Here his clinical research focused specifically on dietetic treatment of patients with Crohn's Disease and he authored the the renowned European Cooperative Crohn's Disease Study IV. ${ }^{9,10}$ In 1994, Herbert Lochs became a full-time professor and head of the Fourth Medical Clinic of the highly regarded University Hospital Charite in Berlin. His research interests continued into the pathogenesis and treatment of inflammatory bowel disease as well as on gastrointestinal cancers. During this time, he was involved in the formulation of some important national and international guideline and position papers. ${ }^{11,12}$
After 15 years in Berlin, he returned to Austria to become the President of the Innsbruck Medical University. His rectorship ended in 2013.

During his scientific carreer Herbert Lochs published $>400$ scientific papers. He was the President of the Austrian Society for Clinical Nutrition (AKE) as well as the German Society for Clinical Nutrition (DGEM). In 1992, he was also President of the ESPEN congress in Vienna.

Herbert Lochs had an outstanding imagination and intuition. This was not only based on his medical education and training. Outside of his career, he was broadly interested in literature, arts, music and theatre. His spectrum farly reached from Homer's lliad to modern writers. He was passionate about great Austrian authors like Thomas Bernhard, Herrmann Broch and Robert Musil. It was really an outstanding experience to hear him reciting Homer by heart or Thomas Bernhard. On his official obituary notice the poem 'A Winter Evening' $(1915)^{13}$ by a great Austrian poet, Georg Trakl, was referred to:

'Whenever snow falls on the window,

Long evening bells rings,

The table is prepared for man

And the house is well prepared.

Many on their wanderings

Come to the gate of dark paths.

Golden blooms the tree of mercy

Form the earth's cool sap.

Wanderer step still within;

Pain petrifies the threshold,

There glitters in pure brightness,

On the table bread and wine.'

Black moods, pain, brightening the space, confessing faith, desire for salvation, homecoming, confidence in what will happen, sense giving... food for thought. Herbert Lochs would have provided wise insights on such thoughts. It is an odd coincidence that Herbert Lochs' grave on the graveyard in Mühlau (Innsbruck) is only $20 \mathrm{~m}$ away from Georg Trakls grave.

Herbert Lochs is survived by his wife, Heide Hörtnagl.

MJ Müller and M Pirlich Institut fur Humanernährung und Lebensmittelkunde, Universitat Kiel, Kiel, Germany E-mail: mmueller@nutrfoodsc.uni-kiel.de

\section{REFERENCES}

1 Hörtnagl $\mathrm{H}$, Winkler $\mathrm{H}$, Lochs $\mathrm{H}$. Membrane proteins of chromaffin granules, dopamine -hydroxylase, a major constituent. Biochem J 1972; 129: 187-195.

2 Lochs $\mathrm{H}$, Morse EL, Adibi SA. Mechanism of hepatic assimilation of dipeptides. Transport versus hydrolysis. J Biol Chem 1986; 261: 14976-14981.

3 Lochs H, Morse EL, Adibi SA. Uptake and metabolism of dipeptides by human red blood cells. Biochem J 1990; 271: 133-137.

4 Lochs H, Williams PE, Morse EL, Abumrad NN, Adibi SA. Metabolism of dipeptides and their constituent amino acids by liver, gut, kidney, and muscle. Am J Physiol 1988; 254: E588-E594. 
5 Lochs H, Roth E, Gasic S, Hübl W, Morse EL, Adibi SA et al. Splanchnic renal, and muscle clearance of alanylglutamine in man and organ fluxes of alanine and glutamine when infused in free and peptide forms. Metabolism 1990; 39: 833-836

6 Lochs H, Hübl W, Gasic S, Roth E, Morse EL, Adibi SA et al. Glycylglutamine: metabolism and effects on organ balances of amino acids in postabsorptive and starved subjects. Am J Physiol 1992; 262: E155-E160.

7 Hübl W, Druml W, Roth E, Lochs H. Importance of liver and kidney for the utilization of glutamine-containing dipeptides in man. Metabolism 1994; 43: 1104-1107.

8 Ockenga J, Borchert K, Stüber E, Lochs H, Manns MP, Bischoff SC et al. Glutamineenriched total parenteral nutrition in patients with inflammatory bowel disease. Eur J Clin Nutr 2005; 59: 1302-1309.
9 Lochs $\mathrm{H}$, Steinhardt HJ, Klaus-Wentz B, Zeitz M, Vogelsang $\mathrm{H}$, Sommer $\mathrm{H}$ et al. Comparison of enteral nutrition and drug treatment in active Crohn's disease. Results of the European Cooperative Crohn's Disease Study. IV. Gastroenterology 1991; 101: 881-888.

10 Lochs $\mathrm{H}$. To feed or not to feed? Are nutritional supplements worthwhile in active Crohn's disease? Gut 2006; 55: 306-307.

11 Lochs H, Dejong C, Hammarqvist F, Hebuterne X, Leon-Sanz M, Schütz T et al. DGEM (German Society for Nutritional Medicine) ESPEN Guidelines on Enteral Nutrition: Gastroenterology. Clin Nutr 2006; 25: 260-274.

12 Evans WJ, Morley JE, Argilés J, Bales C, Baracos V, Guttridge D et al. Cancer cachexia-a new definition. Clin Nutr 2008; 27: 793-799.

13 Georg Trakl. Die Dichtungen. Otto Müller Verlag in Salzburg, 1938. Translated according to Winterabend-Georg Trakl www.germanforspalding.org. 